\title{
MENINGKATKAN AKTIFITAS BELAJAR DENGAN MENERAPKAN MODEL READING GUIDE BERBASIS PAIKEM BAGI PESERTA DIDIK KELAS II SEMESTER SATU TAHUN PELAJARAN 2018/2019 DI SD NEGERI 47 MATARAM
}

\author{
Fatimah \\ Guru Kelas II SD Negeri 47 Mataram
}

\begin{abstract}
Abstrak. Penelitian ini bertujuan untuk mengetahui efektifitas penerapan pendekatan Model Reading Guide Berbasis PAIKEM dalam upaya meningkatkan aktifitas belajar Peserta didik Kelas II SD Negeri 47 Mataram. Manfaat penelitian ini adalah sebagai bahan kajian dan bahan temuan dalam pelaksanaan proses pembelajaran di kelas senyatanya. Bagi guru untuk meningkatkan kompetensi dalam proses pembelajaran dan bagi peserta didik untuk meningktakan motivasi belajar yang berdampak meningkatnya hasil belajar peserta didik. Penelitian ini dilaksanakan dua siklus, masing-masing siklus kegiatannya adalah; perencanaan, pelaksanaan, observasi dan refleksi. Hasil akhir tindakan pada siklus II menunjukkan bahwa hasil observasi guru memperoleh skor rata-rata $(4,64)$ dan hasil observasi peserta didik mencapai skor rata-rata $(4,46)$. Sedangkan hasil dari peningkatan aktifitas belajar peserta didik adalah meningkatnya perolehan hasil belajar peserta didik mencapai nilai rata-rata $(88,65)$, artinya indikator keberhasilan $(\geq 70,00)$ telah terlampaui. Karena indikator keberhasilan telah terbukti penelitian dinyatakan berhasil dan dihentikan pada siklus II.
\end{abstract}

\section{Kata Kunci: Motivasi Belajar, Pendekatan Model Reading Guide}

\section{PENDAHULUAN}

Di SD Negeri 47 Mataram secara umum pelaksanaan proses pembelajaran sudah mengarah ke peserta didik aktif, kegiatan pembelajaran di kelas rendah lebih memberdayakan peran aktif dari peserta didik untuk menampilkan pengalaman belajarnya di lingkungan sekolah, masyarakat, di keluarga yang selanjutnya di implementasikan dalam proses pembelajaran di kelas senyatanya sesuai dengan karakteristik mata pelajaran uang sedang di pelajarinya. Pembelajaran yang demikian sesungguhnya merupakan penerapan kurikulum tahun 2013 yang sudah dilaksanakan di SD Negeri 47 Mataram. Dibalik keterlaksanaan pembelajaran berdasarkan kurikulum tahun 2013 masih ada juga guru yang menerapkan pola pembelajaran guru sentris, alasannya peserta didik kelas rendah masih perlu bimbingan dengan kata-kata maupun ceramah yang diharapkan semua peserta didik mampu memahaminya.

Proses pembelajaran yang terjadi di kelas II SD Negeri 47 Mataram selama ini kecendrungan masih di dominasi oleh guru sentris, selama pembelajaran berlangsung guru aktif menjelaskan materi, membimbing, mengarahkan, dan sesekali memarahi peserta didik yang dianggap melanggar tata tertib selama proses pembelajaran. Peserta didik duduk manis mendengarkan penjelasan guru, kesempatan untuk mengemukakan pendapat sangat terbatas sehingga peserta didik tak ubahnya seperti kertas kosong yang masih putih bersih. coretan-coretan pada buku itu hanya mencatat apa saja yang disuruh oleh guru kelas. Peserta didik kurang bergairah untuk mengikuti pelajaran pelajaran yang diberikan oleh guru, apalagi merubah pola pikir peserta didik yang diharapkan mengarah pada pembelajaran peserta didik aktif sangat sulit didapatkan.

Rendahnya aktifitas belajar peserta didik kelas II SD Negeri 47 Mataram disebabkan karena: 1) kurangnya antusias peserta didik selama proses pembelajaran yang cenderung didominasi oleh guru (guru sentris), 2) pemahaman nilai kebersamaan peserta didik akan pentingnya kebersamaan sesama teman di kelas kurang dioptimalkan, 3) peserta didik seakan-akan kurang peduli terhadap materi pelajaran/rasa ingin tahu sangat rendah, 4) kebanyakan peserta didik berasal dari berbagai kecamatan di Kota Mataram yang memiliki karakteristik 
berbeda-beda sehingga ketika guru menjelaskan materi pelajaran berprilaku yang aneh-aneh sesuai dengan pembiasaaan di kampung halamannya, 5) tingkat kedisiplinan peserta didik masih sangat rendah, karena usia kelas II adalah usia bermain, sehingga selama proses pembelajaran terdengar ribut bahkan ada yang berkelahi, ada yang keluar masuk kelas tanpa permisi.

Banyak solusi yang dapat dilakukan oleh peneliti dalam upaya meningkatkan aktifitas belajar peserta didik kelas II SD Negeri 47 Mataram, diantaranya yaitu dengan menerapkan model pembelajaran "Reading Guide" berbasis PAIKEM. Model pembelajaran ini memiliki keunggulan bila dibandingkan dengan model pembelajaran yang lain yaitu: 1) peserta didik lebih berperan aktif, 2) materi dapat diselesaikan dalam kelas, 3) memotivasi peserta didik untuk senang membaca, 4) membangkitkan minat membaca, 5) mengerti peserta didik yang serius dan tidak serius, 6) peserta didik dituntut untuk teliti dalam menjawab soal, 7) guru mudah mengetahui kelemahan dan kelebihan peserta didik dalam membaca, 8) adanya keseimbangan dalam mengembangkan ranah kognitif, afektif, dan psikomotorik, dan 9) guru mudah mengetahui dan memahami peserta didik yang malas dan yang rajin.

Untuk membuktikan dugaan itu maka perlu diadakan Penelitian Tindakan Kelas (PTK) dengan judul "Meningkatkan Aktifitas belajar Dengan Menerapkan model Reading Guide Berbasis PAIKEM Bagi Peserta Didik kelas II Semester Satu Tahun Pelajaran 2018/2019 di SD Negeri 47 Mataram”.

\section{Rumusan Masalah}

Apakah penerapan model pembelajaran Reading Guide berbasis PAIKEM dapat meningkatkan aktifitas belajar peserta didik kelas II Semester Satu Tahun Pelajaran 2018/2019 di SD Negeri 47 Mataram?

\section{Tujuan Penelitian}

untuk mengetahui efektifitas penerapan model Reading Guide berbasis PAIKEM dalam upaya meningkatkan aktifitas belajar peserta didik kelas II SD Negeri 47 Mataram Semester Satu Tahun Pelajaran 2018/2019.

\section{Manfaat Penelitian}

- Bagi Guru

Penelitian ini sangat bermanfaat bagi guru kelas II SD Negeri 47 Mataram dalam upaya mengembangkan model pembelajaran yang merujuk pada pembelajaran peserta didik aktif dengan menerapkan model Reading Guide berbasis PAIKEM dalam proses pembelajaran di kelas senyatanya. Disamping itu manfaat lain hasil penelitian ini adalah untuk meningkatkan aktifitas belajar peserta didik Kelas II SD Negeri 47 Mataram sehingga dalam proses pembelajaran terjadi interaksi timbal balik antara guru dengan peserta didik, peserta didik dengan peserta didik yang lain.

\section{- Bagi Peserta Didik}

Penelitian Tindakan Kelas (PTK) ini sangat bermanfaat bagi peserta didik kelas II SD Negeri 47 Mataram dalam upaya meningkatkan aktifitas belajarnya melalui pola pembelajaran yang merujuk ke peserta didik aktif sehingga hasil belajar peserta didik dapat ditingkatkan.

\section{KAJIAN PUSTAKA}

\section{Aktifitas belajar}

Aktivitas belajar adalah aktivitas yang bersifat fisik maupun mental. Dalam proses belajar kedua aktivitas itu harus saling berkaitan. Lebih lanjut lagi piaget menerangkan dalam buku Sardiman bahwa jika seorang anak berfikir tanpa berbuat sesuatu, berarti anak itu tidak berfikir (Sardiman, 2011:100).

Nanang Hanafiah dan Cucu Suhana (2010:24) menjelaskan bahwa aktivitas belajar dapat memberikan nilai tambah (added value) bagi peserta didik, berupa halhal berikut ini:

1. Peserta didik memiliki kesadaran (awareness) untuk belajar sebagai wujud adanya aktifitas internal untuk belajar sejati.

2. Peserta didik mencari pengalaman dan langsung mengalami sendiri, yang dapat memberikan dampak terhadap pembentukan pribadi yang integral.

3. Peserta didik belajar dengan menurut minat dan kemampuannya.

4. Menumbuh kembangkan sikap disiplin dan suasana belajar yang demokratis di kalangan peserta didik. 
5. Pembelajaran dilaksanakan secara konkret sehingga dapat menumbuh kembangkan pemahaman dan berfikir kritis serta menghindarkan terjadinya verbalisme.

6. Menumbuh kembangkan sikap kooperatif dikalangan peserta didik sehingga sekolah menjadi hidup, sejalan dan serasi dengan kehidupan di masyarakat di sekitarnya.

\section{Reading Guide}

Ciri-ciri Metode Pembelajaran

Reading Guide: 1) Adanya bahan bacaan (referensi) yang isinya sesuai dengan tema yang akan diajarkan; 2) Adanya tugas yang harus dikerjakan peserta didik yang berupa pernyataan-pernyataan yang harus disempurnakan atau dilengkapi oleh peserta didik sesuai dengan isi bacaan yang telah mereka baca, 3) Adanya interaksi persepsional antar anggota dalam kelompok, jika dilakukan secara kelompok.

Kelebihan dan Kekurangan Metode Reading Guide. Kelebihan: 1) Peserta didik lebih berperan aktif, 2) Materi dapat diselesaikan dalam kelas, 3) Memotivasi peserta didik untuk senang membaca, 4) Membangkitkan minat membaca, 5) Mengerti peserta didik yang serius dan tidak serius, 6) Peserta didik dituntun untuk teliti dalam menjawab soal, 7) Guru mudah mengetahui kelemahan dan kelebihan siswa dalam membaca, 8) Adanya keseimbangan dalam mengembangkan ranah kognitif, afektif, dan psikomotorik, 9) Guru mudah mengetahui dan memahami peserta didik yang malas dan yang rajin. sedangkan kelemahan adalah: 1) Kurang efektif dalam membaca karena singkatnya waktu, 2) Kadang membuat jenuh peserta didik.

Tujuan Metode pembelajaran Reading Guide: 1) Memberikan fokus perhatian peserta didik terhadap poin-poin penting yang ada dalam bahan bacaan melalui kisi-kisi yang berupa tugas melengkapi atau menyempurnakan pernyataan-pernyataan yang terkait dengan isi materi yang terdapat dalam bahan bacaan, dan 2) Menciptakan kerjasama antar anggota dalam kelompok, jika metode ini dilakukan secara kelompok.

\section{Langkah-langkah}

mengimplementasikan

metode

Reading Guide: 1) Siapkan bahan ajar yang berupa teks tulis yang substansinya sesuai dengan materi/tema yang ditentukan dalam Kompletensi Dasar (KD), 2) Siapkan kisi-kisi yang berupa tugas yang terdiri dari beberapa pertanyaan/pernyataan yang belum lengkap atau sempurna sesuai dengan tujuan pembelajaran yang ingin dicapai sebagaimana yang telah dirumuskan dalam Indikator Pencapaian Kompetensi (IPK), 3) Bagikan bahan ajar yang berupa teks tulis dan kisi-kisi yang berupa pertanyaan/pernyataan yang belum lengkap tersebut kepada para peserta didik (bisa secara kelompok atau individu), 4) Mintalah kepada masing-masing kelompok atau individu untuk membaca dan mempelajari bahan ajar dan mengisi kisi-kisi tersebut, 5) Kemudian setelah peserta didik mengerjakan tugas mintalah kepada mereka baik secara kelompok ataupun secara individu untuk mempresentasikan hasil kerjanya masing-masing, 6) Berikan konfirmasi (klarifikasi) kepada para peserta didik setelah mereka selesai mempresentasikan hasil kerjanya.

\section{Pembelajaran PAIKEM}

Penerapan PAIKEM di latarbelakangi oleh kenyataan bahwa model pembelajaran selama berlangsung ini cenderung membuat siswa merasa malas dan bosan dalam belajar, dimana siswa hanya duduk pasif mendengarkan guru berceramah, tanpa memberikan reaksi apapun kecuali mencatat dibuku tulis atas apa yang diucapkan oleh guru mereka. Hal ini berakibat pada kurang optimalnya penguasaan materi pada diri peserta didik.

Pembelajaran PAIKEM adalah sebuah pembelajaran yang memungkinkan peserta didik untuk mengerjakan kegiatan yang beragam dalam rangka mengembangkan keterampilan dan pemahamannya, dengan penekanan peserta didik belajar sambil bekerja, sementara guru menggunakan berbagai sumber dan alat bantu belajar (termasuk pemanfaatan lingkungan), supaya pembelajaran lebih menarik, menyenangkan dan efektif. 
Pendekatan PAIKEM sebagai sebuah strategi pembelajaran, memiliki 5 kriteria yang bisa dipaparkan sebagai berikut :

1. Pembelajaran Aktif: Baik Pendekatan Cara belajar siswa aktif (CBSA) maupun pendekatan Keterampilan Proses (PKP), sangat mengutamakan tingkat keaktifan siswa dalam proses pembelajaran. Suasana pembelajaran aktif dapat memberikan atmosfer berbeda di dalam ruang kelas. Sementara itu pembelajaran yang pasif dapat menimbulkan suasana pembelajaran yang monotan dan menjemukan, karena satu-satunya sumberasan. pengetahuan dikelas adalah guru.

2. Pembelajaran Inovatif: Pembelajaran inovatif bisa mengadaptasi dari model pembelajaran menyenangkanyang bisa membuat siswa terbebas dari kejenuhankejenuhan pembelajaran. Model pembelajaran inovatif ini tentunya berbed jauh dari model pembelajaran konvensional yang memang sudah menjadi kebiasaan dalam pembelajaran. Guru mencoba untuk menanamkan pemikiran "Learning is fun" kepada semua peserta didiknya yang merupakan kunci yang diterapkan dalam pembelajaran inovatif. Jika siswa sudah menanamkan hal ini di pikirannya tidak akan ada lagi siswa yang pasif di kelas, perasaan tertekan dengan tenggat waktu tugas, kemungkinan kegagalan, keterbatasan pilihan, dan tentu saja rasa bosan.

3. Pembelajaran Kreatif : Pembelajaran kreatif menekankan pada pengembangan kreatifitas, baik pengembangan kemampuan imajinasi dan daya cipta (mengarang, membuat kerajinan tangan, mempraktekkan kesenian dll) maupun pengembangan kemampuan berpikir kreatif. Pengembangan kemampuan berpikir kreatif haruslah seimbang dengan kemampuan berpikir rasional logis.

4. Pembelajaran Efektif : Aspek efektifitas pembelajaran merupakan kriteria penting dalam setiap pembelajaran. Suatu pembelajaran disebut efektif manakala pembelajaran tersebut telah mencapai tujuan pendidikan. Tujuan yang diinginkan dalam pembelajaran itu mencakup pada penguasaan IPTEKS sebagai bahan ajar, pembentukan keterampilan atau kemampuan belajar yang lebih efektif dan efisien (belajar mengenai bagaimana cara belajar), bahkan pembentukan kemampuan meta-kognisi (kemampuan pengendalian proses kognitif itu sendiri).

5. Pembelajaran Menyenangkan

Pembelajaran menyenangkan merupakan pembelajran yang didesain sedemikian rupa sehingga memberikan susana penuh keceriaan, menyenangkan, dan yang paling utama, tidak membosankan, peserta didik. Suasana seperti itu akan membuat peserta didik bisa lebih terfokus pada kegiatan belajar-mengajar dikelasnya, sehingga curah perhatiannya akan lebih tinggi. Tingginya tingkat curah perhatian tersebut, akan meningkatkan hasil belajar.

Pelaksanaan pembelajaran yang mengutamakan aspek keaktifan, kreatifitas dan inovatif, sehingga membuat pembelajaran menjadi efektif dan menyenangkan, menuntut guru untuk menguasai berbagai metode mengajar serta keterampilan dasar mengajar. Penguasaan berbagai metode mengajar tersebut akan memberi keleluasaan untuk memilih metode yang sesuai dengan metode yang sesuai dengan tujuan, materi, peserta didik dan aspek-aspek lainnya, sehingga prinsip-prinsip PAIKEM dapat diterapkan secara optimal.

Prinsip-prinsip pembelajaran

PAIKEM antara lain: 1) Mengalami : Peserta didik terlibat secara aktif baik fisik, mental maupun emosional. Melalui pengalaman langsung pembelajaran akan lebih memberi makna kepada sisa dari pada hanya mendengarkan, 2) Komunikasi : Kegiatan pembelajaran memungkinkan terjadinya komunikasi antara guru dan peserta didik, 3) Interaksi : Kegiatan pembelajarannya memungkinkan terjadinya interaksi multi arah, 4) Refleksi : Kegiatan pembelajarannya memungkinkan peserta didik memikirkan kembali apa yang telah dilakukan. Proses refleksi sangat perlu dilakukan untuk mengetahui sejauhmana ketercapaian proses pembelajaran.

Secara garis besar, PAIKEM dapat digambarkan sebagai berikut: 1) Siswa terlibat dalam berbagai kegiatan yang mengembangkan pemahaman dan 
kemampuan mereka dengan penekanan pada belajar melalui berbuat, 2) Guru menggunakan berbagai alat bantu dan berbagai cara dalam membangkitkan semangat, termasuk menggunakan lingkungan sebagai sumber belajar untuk menjadikan pembelajaran menarik, menyenangkan, dan cocok bagi siswa, 3) Guru mengatur kelas dengan memajang buku-buku dan bahan belajar yang lebih menarik dan menyediakan 'pojok baca', 4) Guru menerapkan cara mengajar yang lebih kooperatif dan interaktif, termasuk cara belajar kelompok, 5) Guru mendorong siswa untuk menemukan caranya sendiri dalam pemecahan suatu masalah, untuk mengungkapkan gagasannya, dan melibatkam siswa dalam menciptakan lingkungan sekolahnya.

\section{Hipotesis Tindakan}

Penerapan model Reading Guide berbasis PAIKEM dapat meningkatkan aktifitas belajar peserta didik kelas II SD Negeri 47 Mataram Semester Satu Tahun Pelajaran 2018/2019.

\section{METODE PENELITIAN Setting Penelitian}

Penelitian tindakan kelas (PTK) ini akan dilaksanakan di kelas II SD Negeri 47 Mataram Semester Satu Tahun Pelajaran 2018/2019, dengan jumlah Peserta didik 37 orang

\section{Faktor yang Diteliti}

1. Faktor Guru: yaitu dengan mengamati cara guru membuat Rencana Pelaksanaan Pembelajaran (RPP) dan pelaksanaannya dalam pembelajaran di kelas senyatanya dengan menerapkan pendekatan Model Reading Guide berbasis PAIKEM dalam upaya meningkatkan aktifitas belajar Peserta didik Kelas II SD Negeri 47 Mataram.

2. Faktor Peserta didik: yaitu peningkatan aktifitas belajar Peserta didik yang terlihat pada perilaku Peserta didik selama proses pembelajaran, yang berdampak pada peningkatan hasil belajar peserta didik Kelas II Semester Satu Tahun Pelajaran 2018/2019 di SD Negeri 47 Mataram.

\section{Rencana Tindakan}

Tindakan nyata yang dilakukan oleh guru selaku peneliti adalah dengan menggunakan siklus. Gambaran siklus dalam penelitian ini adalah sebagai berikut:

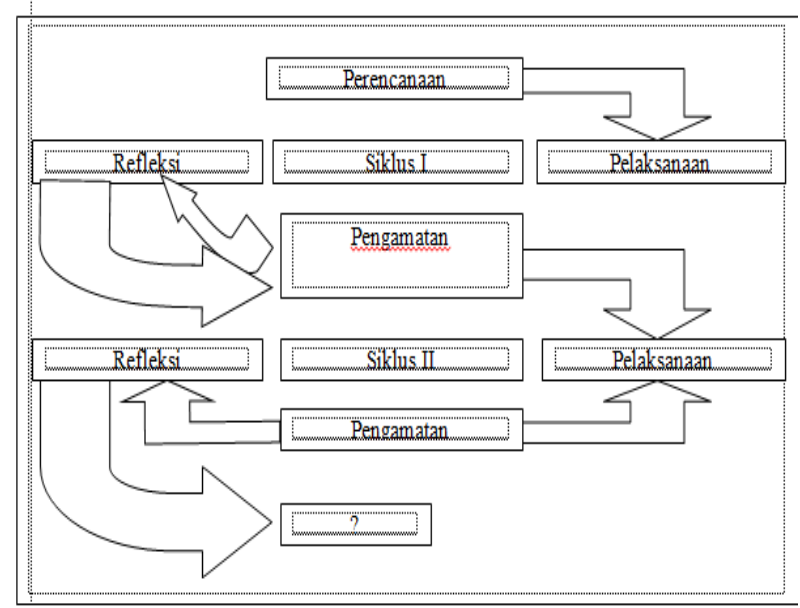

Setiap siklus selama penelitian ini berisi 4 (empat) tahapan yaitu: 1) Perencanaan (Planning), 2) Pelaksanaan (Action), 3) Observasi (Observation), dan 4) Refleksi (Reflection).

\section{Siklus Tindakan \\ SIKLUS I}

\section{Tahap Perencanaan (Planning)}

1. Pada tahapan ini guru selaku peneliti melakukan kegiatan-kegiatan sebagai berikut:

2. Menyusun Rencana Pelaksanaan Pembelajaran (RPP) dengan skenario sesuai dengan aturan main model pembelajaran Model Reading Guide berbasis PAIKEM.

3. Menyiapkan sumber, bahan, dan semua alat yang digunakan dalam penelitian.

4. Menyusun/membuat lembar observasi guru dan lembar observasi Peserta didik.

5. Menyusun alat evaluasi.

\section{Tahap Pelaksanaan (Action)}

Pada tahapan ini guru selaku peneliti melaksanakan proses pembelajaran dengan penerapan Model Reading Guide berbasis PAIKEM dengan skenario sebagai berikut :

1. Guru membimbing peserta didik membaca/pengenalan huruf dengan menggunakan alat peraga berupa papan panel dan potongan huruf.

2. Guru meminta semua peserta didik secara berurutan untuk maju membaca/menempel huruf di papan.

\section{Tahap Observasi (Observation)}

1. Observasi guru : 
Dilakukan oleh pengawas pembimbing selaku observer guru dalam melaksanakan proses pembelajaran di kelas senyatanya.

2. Observasi Peserta didik :

Dilaksanakan oleh guru kelas II sekaligus sebagai peneliti dalam Penelitian Tindakan Kelas (PTK) pada kegiatan diskusi kelompok.

\section{Tahap Refleksi (Reflection)}

1. Renungan hasil perolehan data

2. Pengolahan dan analisa data hasil penelitian

3. Mencocokkan hasil analisa data dengan indikator keberhasilan

4. Rencana perbaikan dan tindak lanjut

\section{SIKLUS II}

Pada siklus ini semua kegiatan dan tahapan selama penelitian adalah sama, sifatnya mengulang dan memperbaiki terhadap tindakan yang masih memerlukan penyempurnaan dan pembenaran sebagaimana mestinya.

\section{Data dan Cara Pengambilannya.}

\section{Sumber Data}

Yang menjadi sumber data dalam penelitian tindakan kelas (PTK) ini adalah semua Peserta didik kelas II Semester Satu Tahun Pelajaran 2018/2019 di SD Negeri 47 Mataram.

\section{Jenis Data}

Adapun jenis data yang dikumpulkan dalam pelaksanaan penelitian tindakan kelas (PTK) ini meliputi :

- Jenis data yang berasal dari guru selaku peneliti

1). Data tentang Rencana Pelaksanaan Pembelajaran (RPP)

2). Data Pelaksanaan Pembelajaran

- Jenis data yang berasal dari Peserta didik:

1). Data kemajuan motivasi dari Peserta didik

2). Data hasil belajar Peserta didik/dampak dari peningkatan aktifitas belajar

\section{Cara Pengambilan data}

- Data kegiatan pembelajaran diambil dari RPP yang dibuat oleh guru dan lembar observasi pelaksanaan Model Reading Guide berbasis PAIKEM

- Data kemajuan aktifitas belajar; diambil dari lembar observasi selama proses pembelajaran.
- Data kemajuan hasil belajar; diambil dari nilai pada saat tes tertulis yang dilaksanakan pada akhir proses pembelajaran.

Indikator Keberhasilan dan Teknik analisa data

\section{Teknik analisa data}

Untuk menganalisis data akan dilakukan melalui analisis deskriptif kuantitatif melalui pendataan, analisis dan pembahasan terhadap data yang diperoleh dengan mencocokkan tingkat keoptimalan terhadap capaian indikator keberhasilan yang ada.

\section{Indikator Keberhasilan}

1. guru telah dinyatakan berhasil melaksanakan proses pembelajaran dengan pendekatan Model Reading Guide berbasis PAIKEM, bila telah mencapai skor rata-rata $\geq 4,00$

2. Aktifitas belajar Peserta didik kelas II dinyatakan telah meningkat jika $85 \%$ dari jumlah Peserta didik telah memperoleh skor perolehan skor rata-rata $\geq 4,0$, dan dampaknya adalah hasil belajar peserta didik semakin meningkat dan diharapkan mencapai $\geq 70,00$

\section{HASIL DAN PEMBAHASAN DESKRIPSI SIKLUS I}

\section{Tahap Perencanaan}

Pada tahapan ini yang telah dilakukan oleh guru selaku peneliti adalah; 1) menyusun RPP dengan skenario pembelajaran Model Reading Guide berbasis PAIKEM, 2) telah berhasil menyiapkan alat, sumber, bahan yang diperlukan dalam penelitian, 3) berhasil menyusun instrument observasi guru dan instrument observasi Peserta didik, dan 4) menyusun alat evaluasi.

\section{Tahap Pelaksanaan}

Pada tahap pelaksanaan proses pembelajaran dengan pendekatan Model Reading Guide berbasis PAIKEM ini yang dilakukan oleh guru adalah 1) tentukan bacaan yang akan dipelajari, 2) buatlah pertanyaan-pertanyaan yang akan dijawab peserta didik atau kisi-kisi dan boleh juga bagan atau skema yang dapat diisi oleh mereka dari bahan bacaan yang telah dipilih tadi, 3) bagikan bahan bacaan dengan pertanyaan atau kisi-kisi kepada peserta, 4) tugas peserta adalah mempelajari bacaan tersebut dengan menggunakan pertanyaan 
atau kisi-kisi yang ada. Batasi aktivitas ini sehingga tidak memakan waktu yang berlebihan, 5) bahas pertanyaan atau kisi-kisi tersebut dengan menanyakan jawaban kepada peserta, 6) pada akhir pembelajaran, berilah ulasan atau penjelasan secukupnya, 7) guru melakukan kesimpulan, klarifikasi, dan tindak lanjut

\section{Tahap Observasi}

Observasi guru memperoleh skor rata-rata sebesar 3,43, observasi peserta didik memperoleh skor rata-rata sebesar 3,16 dan hasil tes tertulis peserta didik memperoleh nilai rata-rata sebesar 57,19

\section{Tahap Refleksi}

1. Renungan data hasil perolehan data pada siklus I

2. Pengolahan data hasil observasi guru, Peserta didik dan tes tertulis.

3. Mencocokkan hasil yang ada dengan Indikator keberhasilan.

4. Merencanakan perbaikan terhadap jenis tindakan yang menyebabkan belum tuntas Indikator keberhasilan. Oleh karena Indikator keberhasilan belum terbukti maka penelitian dilanjutkan ke siklus II.

\section{DESKRIPSI SIKLUS II}

\section{Tahap Perencanaan}

Pada tahapan ini jenis kegiatan yang dilakukan masih mengacu pada kegiatan siklus I, bedanya hanya terjadi perbaikan seperlunya yaitu: 1) penyusunan RPP dengan mengacu pada pendekatan Model Reading Guide berbasis PAIKEM dan penyempurnaan pada bagian skenario pembelajaran, 2) menyiapkan alat, sumber, bahan yang diperlukan dalam proses tindakan dikelas senyatanyan, 3) menyiapkan lembar observasi guru dan lembar observasi Peserta didik sebagaimana pada siklus I, 4) menyiapkan alat evaluasi sebagaimana yang telah dibuat pada siklus I.

\section{Tahap Pelaksanaan}

Secara umum tahapan pelaksanaan proses pembelajaran pada siklus II ini masih mengacu pada pelaksanaan proses pembelajaran sebelumnya. Pemecahan yang dilakukan pada proses pembelajaran ini adalah: 1) pelaksanaan proses pembelajaran lebih dioptimalkan, 2) pelaksanaan pembimbingan peserta didik sekaligus observasi Peserta didik lebih di efektifkan.
Utamanya pengamatan Peserta didik yang termotivasi, yang kurang motivasi, Peserta didik yang tidak termotivasi, dengan harapan proses analisa data lebih signifikan, dan 3) pelaksanaan tes tertulis yang merupakan dampak dari peningkatan aktifitas belajar Peserta didik lebih diperketat.

\section{Tahap Observasi}

Observasi guru memperoleh skor rata-rata sebesar 4,64, observasi peserta didik memperoleh skor rata-rata sebesar 4,46 dan hasil tes tertulis peserta didik memperoleh nilai rata-rata sebesar 88,65

\section{Tahap Refleksi}

1. Renungan atas perolehan data hasil observasi guru, observasi Peserta didik, dan hasil tes tertulis sebagai dampak dari peningkatan aktifitas belajar Peserta didik di kelas senyatanya.

2. Pengolahan data hasil observasi guru, observasi Peserta didik dan tes tertulis

3. Mencocokkan perolehan data hasil tindakan dengan Indikator keberhasilan yang telah ditetapkan.

4. Guru memberikan hadiah/reward kepada semua Peserta didik kelas II atas keberhasilannya dalam upaya meningkatkan aktifitas belajar yang berdampak terhadap perolehan hasil belajar sesuai dengan KKM yang telah ditetapkan.

\section{Pembahasan \\ SIKLUS I}

\section{Tahap Perencanaan}

Peneliti telah berhasil menyusun RPP dengan skenario penerapan pendekatan Model Reading Guide berbasis PAIKEM, menyiapkan alat, sumber, bahan yang diperlukan dalam proses pembelajaran, menyusun instrument observasi guru maupun instrument observasi peserta didik mengalami sedikit kendala. Tetapi setelah berkonsultasi kepada pembimbing, kendala yang dihadapi dapat terselesaikan dengan baik.

\section{Tahap Pelaksanaan}

Dalam melaksanakan proses pembelajaran, guru berpedoman dengan skenaario yang telaah direncanakan yaitu penerapan pendekatan Model Reading Guide berbasis PAIKEM dengan urutan kegiaatan ini sebagai berikut: 1) tentukan bacaan yang akan dipelajari, 2) buatlah pertanyaan- 
pertanyaan yang akan dijawab peserta didik atau kisi-kisi dan boleh juga bagan atau skema yang dapat diisi oleh mereka dari bahan bacaan yang telah dipilih tadi, 3) bagikan bahan bacaan dengan pertanyaan atau kisi-kisi kepada peserta, 4) tugas peserta adalah mempelajari bacaan tersebut dengan menggunakan pertanyaan atau kisi-kisi yang ada. Batasi aktivitas ini sehingga tidak memakan waktu yang berlebihan, 5) bahas pertanyaan atau kisi-kisi tersebut dengan menanyakan jawaban kepada peserta, 6) pada akhir pembelajaran, berilah ulasan atau penjelasan secukupnya, 7) guru melakukan kesimpulan, klarifikasi, dan tindak lanjut.

Tahap Observasi

Observasi guru memperoleh skor ratarata 3,43, Hasil observasi Peserta didik dalam upaya peningkatan aktifitas belajar Peserta didik kelas II Semester Satu Tahun Pelajaran 2018/2019 di SD Negeri 47 Mataram diperoleh skor rata-rata $(3,16)$. Dampak dari peningkatan motivasi/belum meningkatnya aktifitas belajar Peserta didik salah satunya dengan hasil tes tertulis yang materinya hanya sekitar yang diajarkan pada saat itu juga, diperoleh nilai rata-rata $(57,19)$ kategori kurang.

\section{Tahap Refleksi}

Hasil analisa data peningkatan aktifitas belajar pada siklus I ini $(3,16)$ sedangkan yang diminta dalam Indikator keberhasilan $(\geq$ 4,0), ini artinya belum berhasil.

Karena Indikator keberhasilan belum tercapai, penelitian tindakan kelas (PTK) dilanjutkan ke siklus II dengan harapan optimalisasi penerapan strategi pembelajaran dengan pendekatan Model Reading Guide berbasis PAIKEM dapat meningkatkan aktifitas belajar Peserta didik kelas II Semester Satu Tahun Pelajaran 2018/2019 di SD Negeri 47 Mataram.

\section{SIKLUS II}

\section{Tahap Perencanaan}

Peneliti menyusun Rencana Pelaksanaan Pembelajaran (RPP) dengan memperhatikan kesalahan-kesalahan pada siklus I. peneliti lebih memfokuskan tentang Rencana strategi jitu sehingga proses pembelajaran dengan pendekatan Model Reading Guide berbasis PAIKEM dapat terelaisasi dengan baik, karenanya dalam penyusunan skenario benar-benar dirinci dari tiap aspek pada proses pembelajaran dengan model Reading Guide.

\section{Tahap Pelaksanaan}

Pada tahap pelaksanaan di siklus II ini pada dasarnya masih mengacu pada pelaksanaan siklus I, yaitu penerapan pendekatan Model Reading Guide berbasis PAIKEM. Bedanya pada siklus ini lebih dioptimalkan.

\section{Tahap Observasi}

Pada siklus II ini hasil observasi memperoleh skor rata-rata $(4,64)$. Upaya meningkatkan aktifitas belajar Peserta didik kelas II Semester Satu Tahun Pelajaran 2018/2019 di SD Negeri 47 Mataram diperoleh skor rata-rata $(4,46)$. Sebagai tolak ukur keberhasilan proses pembelajaran adalah hasil belajar Peserta didik meningkat, dari data hasil perolehan nilai rata-rata tes tertulis adalah $(88,65)$ sementara pada siklus sebelumnya hanya $(57,19)$ berarti mengalami peningkaatan.

\section{Tahap Refleksi}

Hasil analisa data peningkatan aktifitas belajar Peserta didik pada siklus II adalah $(4,46)$ sedangkan Indikator keberhasilan $(\geq$ 4,0). Ini artinya pada siklus II hasilnya telah melampaui Indikator keberhasilan sebesar $(0,46)$, sedangkan hasil belajar rata-rata $(88,65)$ dari indikator keberhasilan $\geq 70,00$, artinya telah melampaui indikator keberhasilan yang ditentukan.

Karena Indikator keberhasilan telah terbukti, maka tidak perlu ada upaya perbaikan dan penyempurnaan. Pendekatan Model Reading Guide berbasis PAIKEM telah mampu meningkatkan aktifitas belajar Peserta didik yang ditandai dengan tercapainya Indikator keberhasilan dan terjadinya peningkatan hasil belajar Peserta didik. "Penelitian Tindakan Kelas (PTK) dihentikan pada siklus II dengan hasil memuaskan."

\section{SIMPULAN DAN SARAN}

\section{Simpulan}

Data komulatif dari hasil penelitian tindakan kelas (PTK) dari siklus I ke Siklus II adalah sebagai berikut:

\begin{tabular}{|c|l|c|c|c|c} 
No & \multicolumn{1}{|c|}{ Jenis Kegiatan } & $\begin{array}{c}\text { Indikator } \\
\text { keberhasilan }\end{array}$ & Siklus I & Siklus II & Keterangan \\
\hline 1. & Observasi Guru & $\geq 4,00$ & 3,43 & 4,64 & Meningkat \\
\hline 2. & Observasi Peserta didik & $\geq 4,00$ & 3,16 & 4,46 & Meningkat \\
\hline 3. & Tes Akhir & $\geq 70,00$ & 57,19 & 88,05 & Meningkat \\
\hline
\end{tabular}


Penerapan pendekatan Model Reading Guide Berbasis PAIKEM sangat efektif upaya untuk meningkatkan aktifitas belajar Peserta didik kelas II Semester Satu Tahun Pelajaran 2018/2019 di SD Negeri 47 Mataram. Fakta telah menunjukkan perolehan rata-rata skor aktifitas belajar Peserta didik pada siklus I $(3,16)$, sedangkan pada siklus II $(4,46)$, hasil belajar siklus I $(57,19)$ dan Siklus II $(88,65)$ sudah melampaui Indikator keberhasilan yang ditetapkan. Penelitian dinyatakan "berhasil" dan dihentikan pada siklus II.

\section{Saran-Saran}

Disarankan kepada guru sejawat untuk melaksanakan Penelitian Tindakan Kelas (PTK) dalam upaya untuk meningkatkan aktifitas belajar Peserta didik sesuai dengan mata pelajaran masing-masing.

Disarankan kepada semua Peserta didik kelas II SD Negeri 47 Mataram untuk membiasakan belajar dengan pendekatan yang kontekstual utamanya strategi yang mampu membangkitkan aktifitas belajar Peserta didik yang dampaknya hasil belajar dapat ditingkatkan seperti yang diharapkan.

\section{DAFTAR PUSTAKA}

A.M. Sardiman, 2005, Interaksi dan Aktifitas belajar Mengajar, Jakarta: PT RajaGrafindo Persada.

Anonim, 2018, dalam https://taufikudin.wordpress.com/cate gory/pengertian-motivasi-belajarsiswa-menurut-para-ahli-definisi/, diambil pada tanggal 11 Agustus 2018, pukul 11.45 wita.
Anonim, 2018, dalam

http://bdkjakarta.kemenag.go.id/index. php? $a=$ artikel\&id $=843$, diambil pada tanggal 11 Agustus 2018, Pukul 12.35 wita

Anonim, 2018, dalam

http://azkiyatunnufus.blogspot.co.id/20 11/12/strategi-pembelajaranpaikem.html, diambil pada tanggal 13 Agustus 2018, pukul 10.55 wita.

Arikunto, s. 2009, Penelitian Tindakan Kelas, Jakarta : Bumi Aksara.

Harun Rasyid dan Mansur, 2008, Penilaian Hasil Belajar, Bandung : CV Wacana Prima.

Lukmanul A, 2008, Perencanaan Pembelajaran, Bandung : CV Wacana Prima. Mukhtar, 2003, Prosedur Penilaian, Jakarta : Rineka Cipta.

Nasution S., 2004, Didaktik Asas-asas

Mengajar, Jakarta: Bumi Aksara.

Nurhadi, 2003, Yasin ,B dan Sendule.A, 2003, Kontekstual dan Penerapannya dalam KBK, Malang : Unitipetas Negeri Malang.

Purwanto Ngalim, 2002, Administrasi Dan Supervisi Pendidikan, Bandung: PT. Remaja Rosdakarya.

Robert E Slavin, 2010, Cooperative Learning Teori, riset dan Praktik, Bandung : Nusa Media.

Sardiman, 2007, Indikator Dan Aktifitas belajar Mengajar, Jakarta : Raja Grafindo Perkasa.

Supriono, 2009, Cooperative Learning Teori dan Aplikasi PAIKEM, Yogyakarta : Pustaka Pelajar. 